\title{
Age associated endothelial dysfunction: Role of oxidative stress, inflammation and Western Diet
}

\author{
Indika Edirisinghe* and Britt M. Burton-Freeman \\ Center for Nutrition Research, Institute for Food Safety and Health, Illinois Institute of Technology, Bedford Park, \\ IL, USA
}

\begin{abstract}
Aging is a major risk factor in the development of cardiovascular diseases attributed to the development of vascular endothelial dysfunction. Reduced bioavailability of endothelial- nitric oxide (NO) synthase (eNOS) and its product NO is considered the key mechanism mediating reduced endothelial function with aging. Vascular oxidative stress and inflammation increase with age and Western diets rich in fat, specifically saturated fat, refined carbohydrates and limited plant foods increase oxidative stress and inflammation. In aged endothelium, Western diets can augment endothelial dysfunction because functional changes have already likely begun. This review discusses possible mechanisms responsible for endothelial dysfunction in aging and the links between endothelial aging and Western diets.
\end{abstract}

\section{Introduction}

Aging is a visible phenomenon reflecting a cascade of mostly invisible patho-physiological changes in the human body. The cardiovascular system is subject to life-style induced changes as well as natural deterioration due to the aging process. During the last 50 years, the number of people over age 60 years has dramatically increased and is expected to continue to increase [1]. Despite the advances in science and medicine, many older people are suffering from age-associated cardiovascular diseases. The vascular endothelium is a critical regulator of vascular homeostasis and endothelial dysfunction contributes to the pathogenesis and clinical expression of cardiovascular diseases. Aging of the endothelium is suggested to contribute to progressive losses in its function. A dysfunctional endothelium results in blood pressure dysregulation,

*Corresponding author: Indika Edirisinghe, $\mathrm{PhD}$, Center for Nutrition Research, Institute for Food Safety and Health, 6502 South Archer Rd, Bedford Park, IL-60501, USA. Tel.: +1 708308 0178; Fax: +1 708563 8178; E-mail: iedirisi@iit.edu. increased vessel atherogenicity and instability and increased thromboembolic disease risk [2]. Several studies have shown age-related declines in endothelial function [3-5] and age is a strong univariate and multivariate predictor of endothelium-dependent vasodilation [6].

In addition to age, emerging evidence suggests that dietary factors have a significant role in modulating endothelial function. Western type diets characterized by high energy, high intake of fats, especially saturated fat, refined carbohydrates and limited plant food are associated with increased markers of endothelial dysfunction [7, 8]. In an aged endothelium, Western diets can augment endothelial dysfunction. On the other hand, it is also possible to enhance endothelial function through dietary approaches that emphasize fewer calories from rapidly digestible carbohydrate and saturated fats and more calories from plant foods rich in polyphenols [9-12]. Therefore, the intention of this review is to provide an overview of age associated endothelial dysfunction specifically focusing on the role of oxidative stress, inflammation and Western dietary patterns. 


\section{Assessing endothelial function and its association with aging}

Endothelial function is clinically assessed by determining changes in blood flow or vessel diameter in response to various stimuli presented to the endothelium $[2,13]$. The two most commonly used techniques to assess endothelial function are strain-gauge plethysmography and flow mediated dilation (FMD). FMD methodology is an ultrasound-based noninvasive, highly technical, valid method for the assessment of endothelial dependent relaxation (EDR). FMD is used as a surrogate marker of macrovascular endothelial function [14]. Peripheral arterial tonometry (PAT) is another relatively non-invasive technique that assesses peripheral microvascular endothelial function [15]. Pulse wave analysis (PWA) also provides useful information about endothelial function by assessing the mechanical properties of the arterial tree [16]. Laser Doppler flowmetry and imaging accompanied by cutaneous perfusion of iontophoresis of acetylcholine and sodium nitroprusside is another method used to measure endothelial function [17]. Endothelial function may also be assessed indirectly by measuring biomarkers of platelet and fibrinolytic function, leucocytes adhesion, and endothelium associated proteins such as von Willebrand factor, vascular-derived microparticle concentration, among others [18-20]. Elevation in these markers is suggestive of endothelial dysfunction. Overall, these tools and biomarkers are useful in the pursuit to understand endothelium's functional capacity, but provide limited mechanistic evidence.

Impaired endothelial function is a well-established response in people with cardiovascular risk factors such as hypertension, diabetes and elevated blood cholesterol concentrations [20-22]. Endothelial dysfunction was shown to be positively correlated with hypertension using intracoronary Doppler and intravascular ultrasound examination [20]. A doubleblind cross-over trial of 12 patients diagnosed with type 2 diabetes indicated that treatment for insulin resistance significantly increased acetylcholine induced vasodilation (maximum forearm blood flow $12.8 \pm 1.3$ vs. control $8.8 \pm 1.3 \mathrm{ml} / 100 \mathrm{ml} ; P<0.05$ ) [23], suggesting therapies targeted at improving insulin sensitivity will also impart endothelium benefits.

Endothelial dependent relaxation (EDR) declines progressively with age $[6,24,25]$. In a cohort study of 119 healthy subjects aged 19 to 69 years, EDR as measured by forearm blood flow declined steadily with increasing age [6]. EDR is predominately associated with endothelial NO synthase (eNOS) enzyme and availability of its product, NO. Several investigations reported that eNOS expression, activation (phosphorylation) and NO bioavailability declines with aging [25-27]. However, a few studies have observed increased expression of eNOS with aging, which may be an adaptive mechanism to increase the bioavailability of NO $[28,29]$. The mechanism of reduced eNOS expression and activity in aging is not fully known; however, several factors have been suggested including changes in growth factors and hormones that decline with age. [30-32]. The most common factors involved in endothelial aging are thought to stem from oxidative stress and inflammation that impact mechanisms that alter NO bioavailability, foam cell formation, MMP expression, Nuclear Factor-KappaB (NFкB) signaling, adhesion molecule, cytokine and chemokine expression. From this perspective, the role of the Western diet in promoting endothelial dysfunction and possibly premature aging of the endothelium becomes apparent through augmentation of systemic oxidative and inflammatory imbalance.

\section{Oxidative stress in aged endothelium}

Oxidative stress is known to increase with advancing age; hence the hypothesis "free radical theory of aging" [33]. Oxidative stress is defined as an excessive accumulation of reactive oxygen species (ROS) in the body beyond the capacity of endogenous antioxidants to balance redox status [34-36]. The endothelium appears to be a tissue where high amounts of oxygen radicals are generated [37-42] (Fig. 1). Removal of the endothelium and inhibition of eNOS has been shown to reduce ROS generation in the aorta of aged rats [43]. Studies on aging in humans have shown that bioavailability of $\mathrm{NO}$ is diminished in parallel with increased levels of endothelium derived ROS [28, 40]. The sources of ROS in aged endothelium include excessive stimulation of $\mathrm{NAD}(\mathrm{P}) \mathrm{H}$ oxidase or from sources such as mitochondrial electron transport chain, xanthine oxidase (XO) and uncoupled eNOS [44-50].

\section{ROS and the endothelium}

Chemical reaction converting $\mathrm{O}_{2}{ }^{-}$to $\mathrm{H}_{2} \mathrm{O}$ is not $100 \%$ efficient in biology. Residual $\mathrm{O}_{2}{ }^{-}$acts directly 


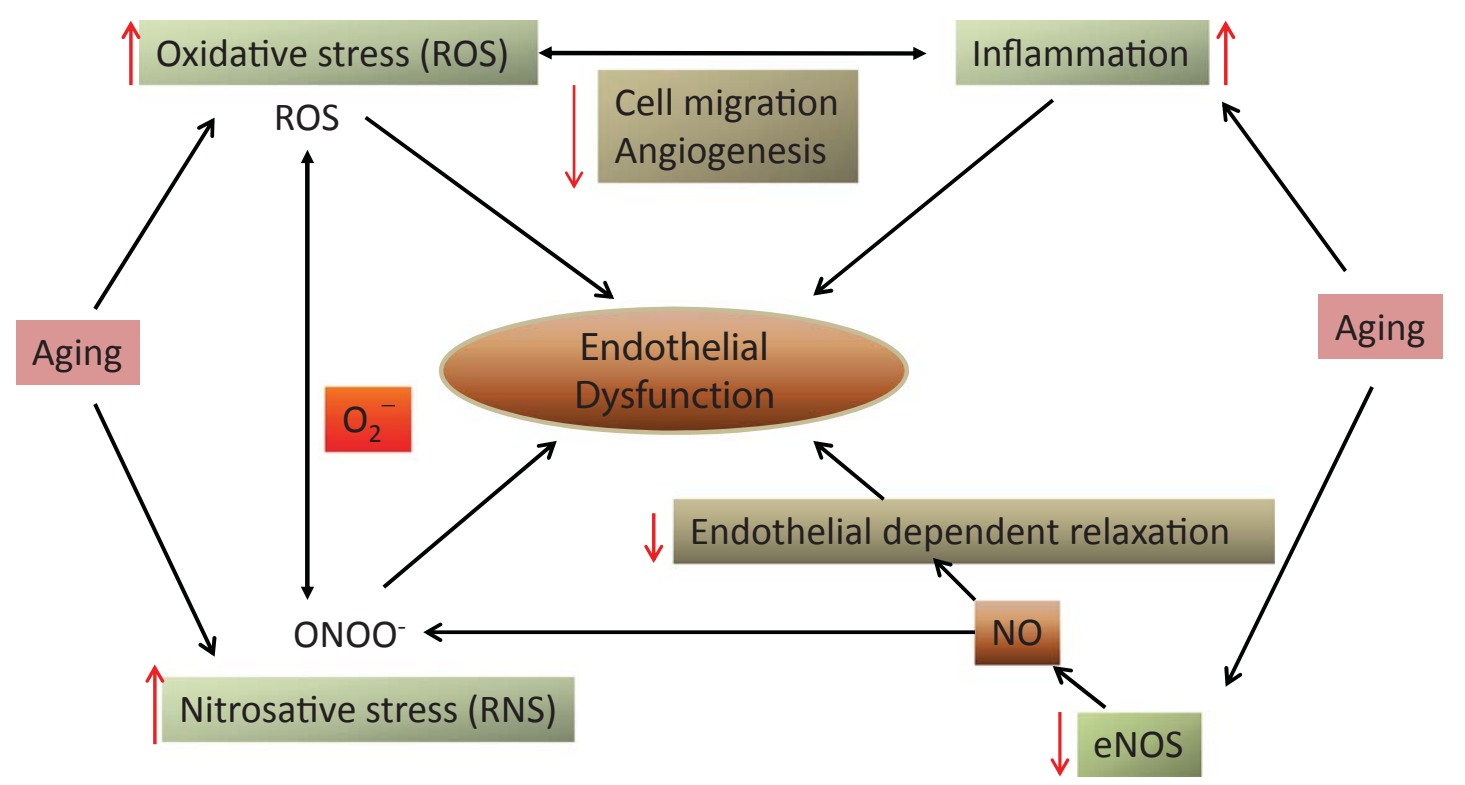

Fig. 1. Age associated endothelial dysfunction. Aging is associated with increased oxidative stress and oxidative damage. The endothelium appears to be a tissue where high amounts of oxygen radicals are generated. Rapid degradation of nitric oxide (NO) by oxygen radicals resulting in peroxynitrite $\left(\mathrm{ONOO}^{-}\right)$formation is one of the most widely accepted mechanisms involved in the endothelial dysfunction. Furthermore, endothelial dysfunction with aging is associated with increased levels of inflammatory markers and closely associated with increased oxidative stress. Impaired expression/activity of endothelial NO synthase (eNOS) resulting in decreased NO production has been shown in aged endothelium. ROS-Reactive oxygen species.

as an oxidant or reacts immediately with NO to produce peroxynitrite $\left(\mathrm{ONOO}^{-}\right)$, a potent and harmful reactive nitrogen species (RNS) in NO-producing endothelial cells [51, 52]. Rapid degradation of $\mathrm{NO}$ by $\mathrm{O}_{2}^{-}$is one of the most widely accepted mechanisms involved in the alteration of the eNOS/NO signaling pathway resulting in impaired endothelial function [38]. Unlike $\mathrm{O}_{2}{ }^{-}$, $\mathrm{ONOO}^{-}$can easily penetrate into cells causing oxidative modifications of macromolecules, such as protein, DNA and lipids via direct oxidative reactions through the nitrosylation of tyrosine and cysteine residue causing impaired cellular signaling $[38,49,53]$. Increased cardiovascular $\mathrm{ONOO}^{-}$ formation has been documented during the aging process $[38,54]$. Furthermore, increased nitrosative stress has been demonstrated in arteries from aged animals [28]. Endothelial function as assessed by FMD has been shown to be inversely associated with nitrotyrosine levels in endothelial cells obtained from brachial artery from aged human subjects [44]. Additionally, in human models, age-dependent nitrotyrosine formation has been documented in mesenteric micro-vessels and endothelial dysfunction been partially restored by scavenging $\mathrm{ONOO}^{-}$[55]. $\mathrm{H}_{2} \mathrm{O}_{2}$ is another stable, yet diffusible ROS that can be converted to hydroxyl radical $\left(\mathrm{OH}^{-}\right)$, which is not stable. Aging exacerbates $\mathrm{H}_{2} \mathrm{O}_{2}$-induced alteration of vascular reactivity in animal models [47, 56]. Collectively, the data strongly support that highly reactive free radical molecules are, at least partially, responsible for age related endothelial dysfunction.

The NAD(P)H oxidases are multi-subunit membrane-spanning proteins with $\mathrm{NAD}(\mathrm{P}) \mathrm{H}$ and FAD binding domains in their C-terminal tails that produce $\mathrm{O}_{2}^{-}$by transferring an electron from $\mathrm{NAD}(\mathrm{P}) \mathrm{H}$ to molecular oxygen $[46,57]$. It has been demonstrated that increased superoxide generation from NAD(P)H oxidase results in impaired vasodilation in aged rat aorta and carotid arteries [43] and inhibition of $\mathrm{NAD}(\mathrm{P}) \mathrm{H}$ oxidases have been shown to increase endothelial function in rat arteries as measured by increased NO bioavailability [46, 58]. The mitochondrion is suggested to be a major source of ROS generation in aged endothelium [48, 59]. Up-regulation of NAD(P)H oxidase in mitochondria during aging supports the speculation that $\mathrm{NAD}(\mathrm{P}) \mathrm{H}$ oxidase plays a significant role in modulating ROS production during aging and the aging process in the 
endothelium [35, 36]. Vascular endothelium is also rich in xanthine oxidase (XO) [60]. Circulating XO has been shown to increase ROS and impact vascular dysfunction in animal models [61-63]. Age related increase in $\mathrm{XO}$ also has been documented in both animal and human models [64]. Newas et al. (2006) indicated that $\mathrm{XO}$, but not $\mathrm{NAD}(\mathrm{P}) \mathrm{H}$ oxidase, acts as the main source of oxidative stress in endothelium [63]. These data are supported by others suggesting a role of XO in vascular aging $[63,65,66]$, however, some reports suggest otherwise $[67,68]$. It appears that involvement of $\mathrm{NAD}(\mathrm{P}) \mathrm{H}$ oxidase and $\mathrm{XO}$ in age associated ROS generation is tissue/species dependent; nevertheless both are responsible for generating ROS.

Another possible source of $\mathrm{O}_{2}{ }^{-}$in vascular aging is uncoupling of eNOS [49]. Inadequate bioavailability of tetrahydrobiopterin $\left(\mathrm{BH}_{4}\right)$, an essential cofactor of eNOS, results in uncoupling of eNOS and is associated with increased levels of $\mathrm{O}_{2}^{-}$[69]. Bioavailability and activity of $\mathrm{BH}_{4}$ is decreased with aging and the mechanism is not clear [70]. $\mathrm{BH}_{4}$ concentrations are reported to be either reduced [71, 72] or unchanged with aging $[73,74]$. However, administration of $\mathrm{BH}_{4}$ in older adults improved endothelial function compared to young people $[74,75]$. Similarly, endothelial dependent vasodilation is increased in response to increased bioavailability of $\mathrm{BH}_{4}$ in old rat arteries [71].

\section{Role of inflammation in aged endothelium}

Low-grade chronic inflammation is another issue linked with aging of the endothelium (Fig. 1). Several studies have demonstrated that impaired endothelial function with aging is associated with increased pro-inflammatory gene expression profiles even in the absence of risk factors for the development of atherosclerosis [76-78]. An activated endothelium is considered a component of endothelial dysfunction, which leads to recruitment of circulating inflammatory cells, such as monocytes and T lymphocytes [79]. A significant body of literature indicates that NFKB activation plays a role in age-related endothelial dysfunction [44, 80, 81]. NFkB activation can induce transcription of genes involved in vascular inflammation including several cytokines, chemokines and cellular adhesion molecules [81]. Among the most commonly measured inflammation markers/mediators are C-reactive protein (CRP), tumor necrosis factoralfa (TNF- $\alpha$ ), Interleukin-6 (IL-6), inducible NOS (iNOS) and endothelial adhesion molecules such as vascular cell adhesion molecule 1 (VCAM-1) and intercellular adhesion molecule 1 (ICAM-1) [82-86]. In the Framingham heart study, FMD was shown to be inversely related to markers of inflammation including CRP, IL-6 and ICAM-1 in an older population [87]. However, after correcting for conventional CVD risk factors, the results were not significant. Nevertheless, inhibition of NFKB signaling has been shown to significantly improve in brachial artery FMD by $74 \%$ $(P<0.0001)$ in healthy overweight and obese middle age and older adults [88].

Age related up-regulation of TNF- $\alpha$ has been described in coronary arteries associated with impaired endothelial function [80]. Chronic inhibition of TNF- $\alpha$ in aged animals significantly improves FMD [89]. Furthermore, it has been demonstrated that TNF- $\alpha$ treatment increases iNOS and endothelial adhesion molecules concentrations, which links with increased NAD(P)H oxidases-derived ROS [28, 80]. Recent research indicated that iNOS expression was increased in vascular tissue of aged rats [90]. The iNOS isoform generated higher amounts of NO than eNOS and therefore rapid reactions resulted in higher amounts of ONOO- $[38,90]$. Selective inhibition of iNOS has been shown to improve age-dependent endothelial function [55]. The involvement of IL-6 in endothelial function is well documented [91, 92]. There is strong evidence that serum IL-6 concentrations increase with age [93-95]. However, the mechanism of increased concentrations of IL-6 in aged populations is not well understood. Oxidative stress may play a significant role in elevated IL-6 concentrations in older populations [96]. CRP, is stimulated by IL-6 and has also been shown to be increased in aged populations [78, 94]. CRP decreases eNOS activity in endothelial cells and inhibits endothelium-dependent NO-mediated vasodilation in vivo and in vitro [97-99]. It has been suggested that CRP inhibits endothelium-dependent NO-mediated dilation in coronary arterioles by producing superoxide from $\mathrm{NAD}(\mathrm{P}) \mathrm{H}$ oxidase mediated mechanism [100].

Endothelial adhesion molecules are proinflammatory proteins that play a significant role in cell-cell/cell-matrix interactions. E-selectin, Pselectin, VCAM-1, and ICAM-1 are the major players of endothelial and leukocyte cell adhesion. These molecules maintain low levels in normal physiological 
conditions, but expression can be enhanced when the endothelium is activated in response to various stimuli such as pro-inflammatory cytokines, ROS, or RNS $[85,101]$. The expressions of adhesion molecules are also up-regulated in aging $[85,101]$. There is evidence that the altered expressions of adhesion molecules may be due to increased oxidative stress, which is characteristic of advanced age and may be prevented by anti-oxidative actions [101].

Modified low density lipoproteins (LDL) are also pro-inflammatory in the vascular cell wall [102]. Oxidatively modified LDL (OxLDL) have increased susceptibility to macrophage uptake via scavenger receptors resulting in foam cell and plaque formation, which promote atherosclerosis development [103]. Although high levels of OxLDL are associated with endothelial dysfunction and atherosclerosis, the data on the association between aging and OxLDL are limited. Recently, a study by Zuliani et al. [104] demonstrated that in an elderly population $(n=1025$, mean age $76 \pm 7$ yrs; females $55 \%)$, LDL$\mathrm{C}$, triglycerides, and HDL-C were the most common determinants of OxLDL concentrations. However, no association was found between higher OxLDLs concentrations and 9 years CVD/cardiac mortality, suggesting that in advanced age the prognostic information added by OxLDLs on CVD/cardiac mortality might be negligible [104].

\section{Diet and the endothelium: Pre-mature "endothelial" aging?}

Several dietary factors have been identified to associate with endothelial dysfunction. Dietary factors associated with increased oxidative stress and inflammation have detrimental effects in older populations due to impaired endogenous protective mechanisms. Regular consumption of energy dense diets, high in fat, specifically saturated fat and refined carbohydrates promote increased oxidative stress and inflammation that can result in a host of inter-related metabolic abnormalities and endothelial dysfunction at any age [105-109]. Although the links between high fat and/or carbohydrate diets on endothelial aging have not been fully elucidated, diet forms an important basis for the deleterious perturbations in aging of the endothelium (Fig. 2). Dyslipidemia and impaired glucose tolerance are the most common metabolic abnormalities associated with chronic intake of high fat and/or carbohydrate diets $[110,111]$ and both affect endothelial function [112-114]. In this section, the role of age- and dietrelated metabolic disturbances that affect the function of the endothelium and possibly contribute to earlyonset endothelial dysfunction will be discussed.

\subsection{Dietary fat, lipemia and endothelial function}

Endothelial function declines with age and dyslipidemia has been shown to augment this process by favoring the generation of ROS [115]. LDL cholesterol and triglyceride concentrations increase, and HDL cholesterol concentration decrease with age [116]. A study carried out by Heitmann BL, (1992) in Danish men and women aged 35-65 years indicated that all blood lipid concentrations were dependent on gender and age. However, they did not consider the contribution of dietary lipids [105]. Age-related disruption of lipid homeostasis/metabolism is suggested to be due to the gradual decline in fractional clearance of LDL, reduced LDL receptor activity, the progressively reduced ability to remove cholesterol through conversion to bile acids, and the decreased activity of the rate-limiting enzyme in bile acid biosynthesis, cholesterol 7 -hydroxylase [117]. Age dependent changes in cholesterol and lipoprotein metabolism has also been linked with the progressive decrease in growth hormones secretion, a characteristic feature of aging [118]. The low levels of testosterone and high free androgens index (testosterone $(\mathrm{nmol} / \mathrm{L}) / \mathrm{SHBG}(\mathrm{nmol} / \mathrm{L}) \times 100)$ have been associated with the atherogenic lipid profile in men $[119,120]$.

Dyslipidemia occurs with poor dietary patterns and reversed with improvements in diet composition such as increased plant foods, fiber, unsaturated fat and reduced intake of saturated fats, red meats and refined grains $[110,111]$. Quality and quantity of dietary fat not only influences the plasma lipid profile, but also endothelial function. Short-term and long-term intervention studies have consistently shown a relationship between higher intake of dietary fat and decreased FMD and increased blood markers of endothelial dysfunction [106, 121-123]. However, it is suggested that diets containing high saturated fat has a more significant role on endothelial dysfunction than total fat content; although both play a role. A study by Steer et al. [106] indicated that a diet providing $35 \%$ energy from fat (Western type meal) significantly decreased endothelial function as measured by forearm 


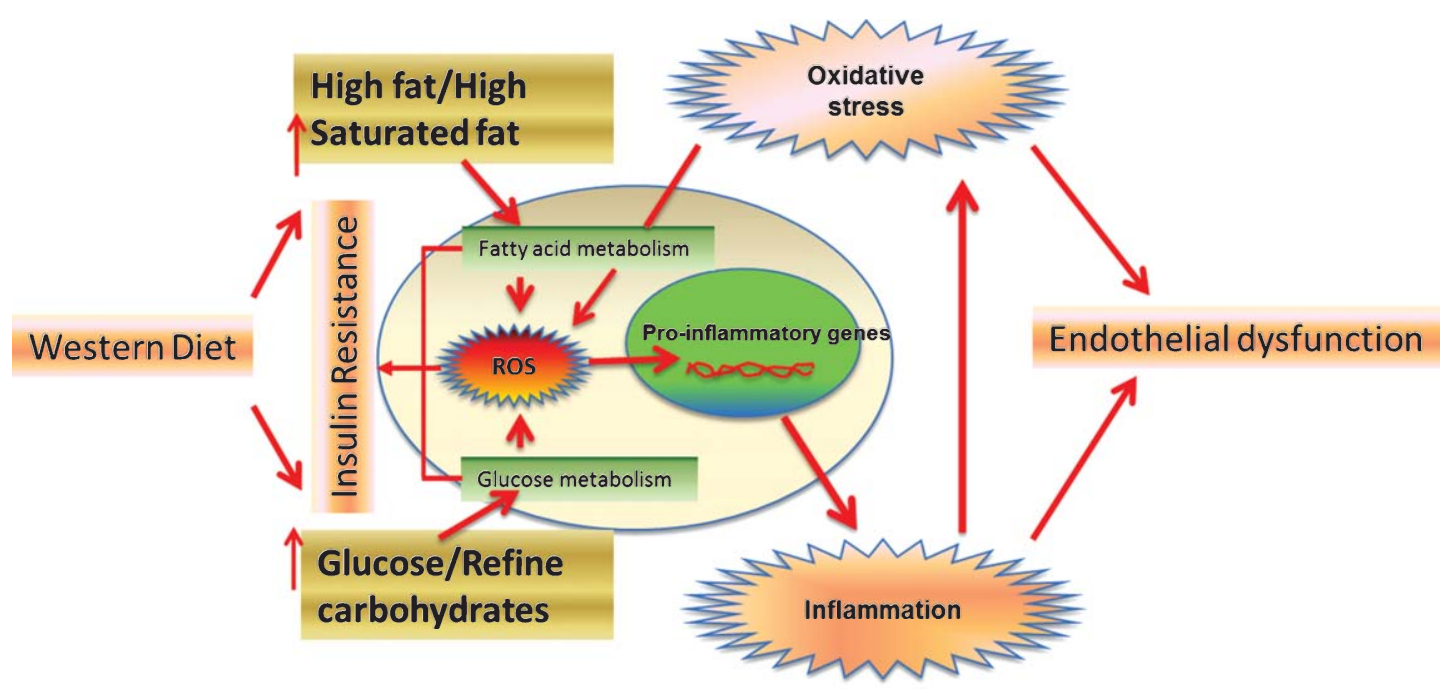

Fig. 2. Endothelial dysfunction and Western diet: Regular consumption of western type diets, which are energy dense and high in fat specifically saturated fat and refined carbohydrates, promote increased oxidative stress and inflammation resulting in a host of metabolic abnormalities such as insulin resistance. Increased oxidative stress and inflammation cause endothelial dysfunction. ROS-Reactive oxygen species.

blood flow after $1 \mathrm{~h}$ consumption compared to meal containing $20 \%$ and $3 \%$ energy from fat in healthy men and women aged 20-30 years [106]. Further, a cross over study with isocaloric diets high in polyunsaturated fatty acids (PUFA), monounsaturated fatty acids (MUFA), or saturated fatty acids (SFA), containing at least $25 \mathrm{~g}$ of the relevant fat or a low-fat control diet showed that SFA impaired FMD compared with all other diets $(5.41 \pm 2.45 \%$ versus $10.80 \pm 3.69 \% ; P=0.01)$ [107]. In contrast to diets high in saturated fats, the Mediterranean-style diet rich in unsaturated fats is associated with cardiovascular risk factor reduction, including improved endothelial function. A randomized, single-blind trial conducted in people with metabolic syndrome subjects showed an improved endothelial function score in the Mediterranean diet intervention group $(+1.9 \pm 0.6$; $P<.001)$ but remained stable in the control group $(+0.2 \pm 0.2 ; P=0.33)$ after 2 years [108]. Similarly, a study conducted in people with type 2 diabetes mellitus showed that FMD measured before (fasting) and several times after a meal $(2 \mathrm{~h}, 4 \mathrm{~h}$ and $6 \mathrm{~h}$ postprandial $)$ increased after the MUFA rich meal by $5.2 \pm 2.5 \%$ and decreased after the SFA-rich meal by $16.7 \pm 6.0 \%$ $(\Delta=-11.5 \pm 6.4 \% ; \mathrm{P}=0.008$ - data expressed as incremental area under the 0-6 h curve) [109].

Elevated concentrations of free fatty acids (FFA) typically observed in insulin resistance decreases endothelial function. Mittermayer et al. [124] showed that infusion of triglyceride/heparin substantially increased FFA concentrations $(P<0.001)$ and reduced endothelium-dependent vasodilation by $38 \pm 17 \%$ $(P=0.024)$ in healthy male subjects [124]. Cholesterol lowering, especially LDL cholesterol has been shown to improve endothelial function as assessed by FMD in human subjects $[125,126]$. A significant improvement in FMD was observed in subjects with LDL cholesterol $<80 \mathrm{mg} / \mathrm{dL}$ in response to lipid-lowering dietary advice and simvastatin treatment over 12 weeks $(5.6 \pm 1.7$ vs. $13.6 \pm 2.6 \%, P<0.028)$ compared to subjects with higher LDL cholesterol concentrations $(4.4 \pm 1.8$ vs. $8.2 \pm 1.6 \%, P=0.173)$ [126]. These data support continued efforts to help people achieve lower LDL cholesterol concentrations.

More than $80 \%$ of the CVD-associated death and disability is attributed to atherosclerosis, a product of excessive accumulation of lipids, inflammatory cells, and connective tissue in the vessel wall [127, 128]. Dysfunction of the endothelium is considered one of the first steps in the atherosclerotic process [129]. The described observations link higher dietary intake of total fat, but particularly saturated fat with endothelial dysfunction along with higher concentrations of circulating lipids and their metabolic products on endothelium dysfunction. Hence, the diet is a critical point of intervention to maintain a healthy endothelium. 


\subsection{Glycemia and endothelial function}

Hyperglycemia is commonly observed in people with diabetes mellitus (both type I and II) and plays an important role in the development and progression of CVD. The glycemic index (GI) is a value used as an indicator of carbohydrate quality reflecting the effect of a food on blood glucose. The glycemic load (GL) is an indicator of both carbohydrate quality and quantity. Epidemiologic data suggest that a high dietary GL from refined carbohydrates increases the risk of CVD with no previous diagnosis of diabetes mellitus [130]. Furthermore, the adverse metabolic effects of hyperglycemia in response to high carbohydrate intake or dietary GL are greatly exaggerated in the presence of insulin resistance [131, 132]. A study assessing the impact of diets differing by GI on endothelial function showed that FMD was significantly lowered after the high glycemic diet $(-0.9 \pm 3.6 \%, P<0.005)$ compared to low glycemic diet $(2.3 \pm 2.6 \%, p>0.05)$ [133].

When the endothelium is exposed to high levels of glucose (hyperglycemia), an array of disruptive intracellular events occur that can lead to impaired endothelial function and atherosclerosis development and progression. Ex vivo experiments with rabbit aorta treated for 6 hours in hyperglycemic media showed reduced acetylcholine-mediated vasodilation compared to normoglycemic controls [114]. Antioxidant administration (eg., superoxide dismutase, catalase, deferoxamine, or allopurinol) reversed the hyperglycemia-associated impairment in vasodilation [114], suggesting that glucose associated suppression of endothelium-dependent vasodilation is mediated through increased production of oxygen-derived free radicals. Hyperglycemia can increase cellular ROS production by several pathways including direct glucose autooxidation [134, 135], mitochondrial superoxide production [136], eNOS uncoupling [137], and Advanced Glycation Endproducts (AGE)-dependent NAD(P)H oxidase activation [138]. Glucose autooxidation and mitochondrial superoxide are considered to be the primary contributors to ROS-mediated endothelial dysfunction induced by hyperglycemia [139]. A study by Kränkel et al. [140] demonstrated that high glucose impairs proliferation, survival, and function of cultured endothelial progenitor cells (EPC) with concomitant decreased NO production and MMP-9 activity [140]. Correction of hyperglycemia by insulin therapy restored the normal EPC pool. In endothelial cells, eNOS uncoupling in response to ROS production further augments oxidative stress under hyperglycemic conditions resulting in endothelial dysfunction [137]. Hyperglycemia leading to AGE production also contributes to ROS production through receptor-mediated NAD(P)H oxidase activation [141]. AGEs bind to multiple cell surface receptors including the "receptor for AGE" (RAGE) [142] that are known to regulate AGEassociated endothelial cell dysfunction. Use of the $\mathrm{NAD}(\mathrm{P}) \mathrm{H}$ oxidase inhibitor diphenyliodonium (DPI) has been shown to significantly attenuate the production of ROS, verifying the involvement of NAD $(\mathrm{P}) \mathrm{H}$ oxidase system, AGE and ROS production [143].

AGEs also decrease eNOS expression and Lcitrulline production in endothelial cells [144]. Indeed, Gao et al. [145] showed that the impaired vasodilation in blood vessels of diabetic mice is endothelium dependent and RAGE sensitive [145]. Involvement of AGE in endothelial dysfunction is confirmed by significantly reducing atherosclerotic plaque formation in diabetic ApoE null mice with pharmacological inhibitors of AGE formation, alagebriumchloride (ALT-711), pyridoxamine dihydrochloride [146]. A human clinical trial using ALT-711 has also demonstrated enhanced arterial compliance and improved FMD in older patients with hypertension [147]. These data indicate that controlling hyperglycemia is critical in maintaining or improving endothelial function.

Chronic hyperglycemia may induce changes in the endothelial cell that accelerates endothelial cell aging [148, 149]. Hyperglycemia is often caused by impaired insulin action or insulin resistance. A significant contribution to the accelerated aging process in insulin-resistant individuals is attributable to endothelial senescence, dysfunction and impaired repair. Impaired insulin signaling leads to insulin resistance and affects several aspects involved in premature aging, such as body composition, mitochondrial activity, and endocrine function. The life expectancy of people with diabetes is estimated to be lower than that of the general population by 9.1 years in males and 6.7 years in females [150]. The identification of longevityassociated genes such as sirtuin and p66Shc in the vascular endothelium and metabolically active cells suggests that the aging process, endothelial dysfunction and insulin resistance are closely linked [151]. The mammalian sirtuin (Sirt) -1 is highly expressed in endothelial cells and controls functions that are critical to suppressing the development of atherosclerosis [152]. A series of experimental studies have shown that Sirt1 plays a role in improving the function of 
endothelial cells. It has been demonstrated that the positive effects of calorie restriction exerts on diabetes and CVD are mediated by sirtuins $[151,152]$.

\section{Dietary approaches to improve endothelial function and slow aging of the endothelium}

Several lines of investigations suggest an important role of dietary factors in modulating endothelial function [153-157]. Diets rich in energy, saturated fat, refined carbohydrates and higher intake of sodium are known to promote endothelial dysfunction [153-156]. Types of fat and carbohydrates play a significant role in modulating endothelial function and have been discussed in previous sections (See dietary fat, lipemia and endothelial function and glycemia and endothelial function). Prospective analysis of the CARDIA study that recruited a population based sample of 5115 black and white men and women aged 18-30 years indicated that dietary patterns are associated with cellular adhesion molecules, known markers of endothelial function [155]. The CARDIA study particularly suggested that cellular adhesion molecules are related longitudinally to dietary patterns. The A Priori Diet Quality Score was inversely related to cellular adhesion molecules, E-selectin, P-selectin, sICAM-1, and VCAM-1. Similarly, in a cross-sectional analysis of 732 women from the Nurse's Health Study data, two major dietary patterns: a Prudent dietary pattern and a Western dietary pattern were compared relative to endothelial function. The data indicated that E-selectin, sICAM-1, and VCAM-1 were positively associated with a Western diet derived through principal components analysis. A Prudent diet that is high in fruits and vegetables and low in red and processed meats, and refined grains was only inversely associated with E-selectin [158].

Conversely, adherence to diets such as the Mediterranean diet rich in fruits, vegetables, fish, olive oil, and nuts is known to associate with reduced risk of CVD [159]. From a nutritional perspective, these types of diets are abundant in essential micronutrients, fiber, polyphenols and emphasize quality macronutrient food sources. Polyphenols have recently been at the forefront of interest for their effects on endothelial function. Data from the PREDIMED study showed an inverse association between habitual polyphenol intake and the risk of major cardiovascular events and higher polyphenol intake was inversely associated with hypertension, a sign of endothelial dysfunction [160]. These findings are supported by acute and chronic clinical studies showing improved FMD responses after dietary polyphenols intake [161-164]. Although polyphenolic compounds have been studied for their role on endothelial function due to their direct antioxidant effects, recent research indicates that these compounds offer indirect protection by activating cell signaling molecules related to endothelial function such as activation of eNOS and modulating inflammatory genes such as NF-кB [165]. Certain polyphenols and/or their phenolic metabolites are suggested to increase NO bioavailability leading to EDR [166]. This may be achieved through various intracellular signaling paths such as altered redox sensitive kinase activity leading to increased NO synthesis (eg., PI3/Akt, eNOS) [167-169], and or modulating genes involved with the endogenous antioxidant defense system, reducing $\mathrm{ONOO}^{-}$formation $[168,170]$. Investigations have also found that higher intakes of dietary polyphenols are associated with decreased levels of oxidized LDL and various inflammatory markers $[7,8$, 171]. Oxidized LDLs promote vascular inflammation and an array of events leading to endothelial dysfunction [172, 173]. Folic acid and antioxidant vitamins such as Vitamins $\mathrm{A}, \mathrm{C}$ and $\mathrm{E}$ also play an important role in modulating endothelial function; although the data are not consistent [159, 174]. The Dietary Guidelines for Americans (DGA, 2010) recommend that people consume at least 2.5 cups of vegetables and 2 cups of fruits daily ( $2000 \mathrm{Kcal} /$ day diet) in order to achieve the varied essential nutrients people need for health and disease risk reduction [175]. However, specific recommendations are not given in relation to daily polyphenolic intake. This is an area ripe for review and consideration in updates of the DGA.

The association between high dietary sodium intake and blood pressure is a well-known as a risk factor for the endothelial dysfunction, while potassium intake attenuates these effects. It has been demonstrated that a $5 \%$ increase of plasma sodium concentration (sodium excess) changes the hardness of endothelium by $25 \%$, leading to endothelial dysfunction [176]. Diets, such as the Dietary Approaches to Stop Hypertension (DASH) diet, that include sodium reduction while increasing potassium intake have been shown to prevent or control hypertension and decrease cardiovascular morbidity and mortality [177, 178]. Furthermore, it has been shown that blood pressure-independent effects of sodium reduce vascular NO bioavailability limiting endothelium-dependent dilation via a mechanism associated with increased levels of ROS generated by 
$\mathrm{NAD}(\mathrm{P}) \mathrm{H}$ oxidase, $\mathrm{XO}$ or uncoupled endothelial $\mathrm{NO}$ synthase within the vascular wall [179].

Poor dietary patterns promote endothelial dysfunction. In aged endothelium, the effects are accentuated $[2,180,181]$. Based on the derived literature, a reasonable hypothesis is that poor dietary habits practiced routinely likely age the endothelium prematurely. Therefore, dietary strategies based on regular consumption of diets emulating Mediterranean dietary patterns, the DASH diet or other diets emphasizing fruits, vegetables, whole grains and intake of low-fat animal products can be used to improve and maintain endothelial function, and to slow down the aging process of the endothelium.

\section{Conclusion}

Advancing age is an important risk factor for the development of many cardiovascular diseases such as atherosclerosis and hypertension. Endothelial dysfunction occurs during the human aging process and is accompanied by declines and/or deactivation of vasodilator substances produced by the endothelium. Persistent oxidative stress and inflammation play a significant role in endothelial function; and diet can influence both. In particular, diets rich in energy, saturated fat and refined carbohydrates promote endothelial dysfunction: augmenting dysfunction in aged endothelium and possibly aging the endothelium prematurely. Several overlapping mechanisms are apparent and related to modern lifestyle and dietary habits. Understanding and elucidating the mechanisms of endothelial (dys)function relative to dietary patterns and various constituents with potential health benefits, such as polyphenols will require continued investment in the field, particularly focused on long-term interventional studies. With diet at the cornerstone of health and disease risk reduction, science supporting development of dietary strategies that people can easily adopt in modern times to support a healthy endothelium and slowing of age-associated declines can have a critical impact on cardiovascular disease development, progression and complication.

\section{References}

[1] Global Health and Aging [Internet]. 2011. Available from: http://www.nia.nih.gov/sites/default/files/global_health_and_ aging.pdf.
[2] Seals DR, Jablonski KL, Donato AJ. Aging and vascular endothelial function in humans. Clin Sci (Lond). 2011;120(9):357-75.

[3] Celermajer DS, Sorensen KE, Spiegelhalter DJ, Georgakopoulos D, Robinson J, Deanfield JE. Aging is associated with endothelial dysfunction in healthy men years before the age-related decline in women. J Am Coll Cardiol 1994;24(2):471-6.

[4] Han L, Bai X, Lin H, Sun X, Chen X. Gender differences in the relationship between age-related carotid intima-media thickness and cardiac diastolic function in a healthy Chinese population. J Card Fail 2013;19(5):325-32.

[5] Trott DW, Luttrell MJ, Seawright JW, Woodman CR. Aging impairs PI3K/Akt signaling and NO-mediated dilation in soleus muscle feed arteries. Eur J Appl Physiol 2013;113(8):2039-46.

[6] Gerhard M, Roddy MA, Creager SJ, Creager MA. Aging progressively impairs endothelium-dependent vasodilation in forearm resistance vessels of humans. Hypertension 1996;27(4):849-53.

[7] Edirisinghe I, Banaszewski K, Cappozzo J, Sandhya K, Ellis CL, Tadapaneni R, et al. Strawberry anthocyanin and its association with postprandial inflammation and insulin. Br J Nutr 106. England2011. p. 913-22.

[8] Burton-Freeman B, Talbot J, Park E, Krishnankutty S, Edirisinghe I. Protective activity of processed tomato products on postprandial oxidation and inflammation: A clinical trial in healthy weight men and women. Mol Nutr Food Res 2012;56(4):622-31.

[9] Marin C, Ramirez R, Delgado-Lista J, Yubero-Serrano EM, Perez-Martinez P, Carracedo J, et al. Mediterranean diet reduces endothelial damage and improves the regenerative capacity of endothelium. Am J Clin Nutr 2011;93(2):267-74.

[10] Marín C, Yubero-Serrano EM, López-Miranda J, PérezJiménez F. Endothelial aging associated with oxidative stress can be modulated by a healthy mediterranean diet. Int J Mol Sci 2013;14(5):8869-89.

[11] Perez-Martinez P, Moreno-Conde M, Cruz-Teno C, Ruano J, Fuentes F, Delgado-Lista J, et al. Dietary fat differentially influences regulatory endothelial function during the postprandial state in patients with metabolic syndrome: From the LIPGENE study. Atherosclerosis 2010;209(2):533-8.

[12] Perez-Martinez P, Garcia-Quintana JM, Yubero-Serrano EM, Tasset-Cuevas I, Tunez I, Garcia-Rios A, et al. Postprandial oxidative stress is modified by dietary fat: Evidence from a human intervention study. Clin Sci (Lond) 119. England 2010. p. 251-61.

[13] Brandes RP, Fleming I, Busse R. Endothelial aging. Cardiovasc Res 2005;66(2):286-94.

[14] Hijmering ML, Stroes ES, Pasterkamp G, Sierevogel M, Banga JD, Rabelink TJ. Variability of flow mediated dilation: Consequences for clinical application. Atherosclerosis 2001;157(2):369-73.

[15] Bonetti PO, Pumper GM, Higano ST, Holmes DR, Jr., Kuvin JT, Lerman A. Noninvasive identification of patients with early coronary atherosclerosis by assessment of digital reactive hyperemia. J Am Coll Cardiol 2004;44(11):2137-41.

[16] Stoner L, Young JM, Fryer S. Assessments of arterial stiffness and endothelial function using pulse wave analysis. Int J Vasc Med 2012;2012:903107. 
[17] Turner J, Belch JJ, Khan F. Current concepts in assessment of microvascular endothelial function using laser Doppler imaging and iontophoresis. Trends Cardiovasc Med 2008;18(4):109-16.

[18] Vischer UM. von Willebrand factor, endothelial dysfunction, and cardiovascular disease. J Thromb Haemost 2006;4(6):1186-93.

[19] Rautou PE, Vion AC, Amabile N, Chironi G, Simon A, Tedgui A, et al. Microparticles, vascular function, and atherothrombosis. Circ Res 2011;109(5):593-606.

[20] Hadi HA, Carr CS, Al Suwaidi J. Endothelial dysfunction: Cardiovascular risk factors, therapy, and outcome. Vasc Health Risk Manag 2005;1(3):183-98.

[21] Panza JA, Quyyumi AA, Brush JE, Epstein SE. Abnormal endothelium-dependent vascular relaxation in patients with essential hypertension. N Engl J Med 1990;323(1): 22-7.

[22] Panza JA. Endothelial dysfunction in essential hypertension. Clin Cardiol 1997;20(11 Suppl 2):II-26-33.

[23] Pistrosch F, Passauer J, Fischer S, Fuecker K, Hanefeld M, Gross $P$. In type 2 diabetes, rosiglitazone therapy for insulin resistance ameliorates endothelial dysfunction independent of glucose control. Diabetes Care 2004;27(2):484-90.

[24] Egashira K, Inou T, Hirooka Y, Kai H, Sugimachi M, Suzuki $\mathrm{S}$, et al. Effects of age on endothelium-dependent vasodilation of resistance coronary artery by acetylcholine in humans. Circulation 1993;88(1):77-81.

[25] Toda N. Age-related changes in endothelial function and blood flow regulation. Pharmacol Ther 2012;133(2): 159-76.

[26] Cau SB, Carneiro FS, Tostes RC. Differential modulation of nitric oxide synthases in aging: Therapeutic opportunities. Front Physiol 2012;3:218.

[27] Dal-Ros S, Bronner C, Auger C, Schini-Kerth VB. Red wine polyphenols improve an established aging-related endothelial dysfunction in the mesenteric artery of middle-aged rats: Role of oxidative stress. Biochem Biophys Res Commun 2012;419(2):381-7.

[28] van der Loo B, Labugger R, Skepper JN, Bachschmid M, Kilo J, Powell JM, et al. Enhanced peroxynitrite formation is associated with vascular aging. J Exp Med 2000;192(12):1731-44.

[29] Goettsch W, Lattmann T, Amann K, Szibor M, Morawietz $\mathrm{H}$, Münter K, et al. Increased expression of endothelin-1 and inducible nitric oxide synthase isoform II in aging arteries in vivo: Implications for atherosclerosis. Biochem Biophys Res Commun 2001;280(3):908-13.

[30] Duckles SP, Miller VM. Hormonal modulation of endothelial NO production. Pflugers Arch 2010;459(6):841-51.

[31] Andersson IJ, Johansson ME, Wickman A, Bohlooly-Y M, Klintland N, Caidahl K, et al. Endothelial dysfunction in growth hormone transgenic mice. Clin Sci (Lond) 2006;110(2):217-25.

[32] Lerman A, Zeiher AM. Endothelial function: Cardiac events. Circulation 2005;111(3):363-8.

[33] Balaban RS, Nemoto S, Finkel T. Mitochondria, oxidants, and aging. Cell 2005;120(4):483-95.

[34] Lambeth JD. NOX enzymes and the biology of reactive oxygen. Nat Rev Immunol 2004;4(3):181-9.
[35] Ago T, Matsushima S, Kuroda J, Zablocki D, Kitazono T, Sadoshima J. The NADPH oxidase Nox4 and aging in the heart. Aging (Albany NY) 2010;2(12):1012-6.

[36] Ago T, Kuroda J, Kamouchi M, Sadoshima J, Kitazono T. Pathophysiological roles of NADPH oxidase/nox family proteins in the vascular system. -Review and perspective-. Circ J 2011;75(8):1791-800.

[37] Higashi Y, Kihara Y, Noma K. Endothelial dysfunction and hypertension in aging. Hypertens Res 2012.

[38] El Assar M, Angulo J, Vallejo S, Peiró C, SánchezFerrer CF, Rodríguez-Mañas L. Mechanisms involved in the aging-induced vascular dysfunction. Front Physiol 2012; $3: 132$.

[39] Dai DF, Rabinovitch PS, Ungvari Z. Mitochondria and cardiovascular aging. Circ Res 2012;110(8):1109-24.

[40] Bachschmid MM, Schildknecht S, Matsui R, Zee R, Haeussler D, A Cohen R, et al. Vascular aging: Chronic oxidative stress and impairment of redox signaling-consequences for vascular homeostasis and disease. Ann Med 2012.

[41] Dröge W. Oxidative stress and aging. Adv Exp Med Biol 2003;543:191-200.

[42] Dröge W, Schipper HM. Oxidative stress and aberrant signaling in aging and cognitive decline. Aging Cell 2007;6(3): 361-70.

[43] Hamilton CA, Brosnan MJ, McIntyre M, Graham D, Dominiczak AF. Superoxide excess in hypertension and aging: A common cause of endothelial dysfunction. Hypertension 2001;37(2 Part 2):529-34.

[44] Donato AJ, Eskurza I, Silver AE, Levy AS, Pierce GL, Gates PE, et al. Direct evidence of endothelial oxidative stress with aging in humans: Relation to impaired endothelium-dependent dilation and upregulation of nuclear factor-kappaB. Circ Res 2007;100(11):1659-66.

[45] Durrant JR, Seals DR, Connell ML, Russell MJ, Lawson BR, Folian BJ, et al. Voluntary wheel running restores endothelial function in conduit arteries of old mice: Direct evidence for reduced oxidative stress, increased superoxide dismutase activity and down-regulation of NADPH oxidase. J Physiol 2009;587(Pt 13):3271-85.

[46] Hamilton CA, Brosnan MJ, Al-Benna S, Berg G, Dominiczak AF. $\mathrm{NAD}(\mathrm{P}) \mathrm{H}$ oxidase inhibition improves endothelial function in rat and human blood vessels. Hypertension 2002;40(5):755-62

[47] Csiszar A, Labinskyy N, Zhao X, Hu F, Serpillon S, Huang Z, et al. Vascular superoxide and hydrogen peroxide production and oxidative stress resistance in two closely related rodent species with disparate longevity. Aging Cell 2007;6(6):78397.

[48] Ungvari Z, Orosz Z, Labinskyy N, Rivera A, Xiangmin Z, Smith $\mathrm{K}$, et al. Increased mitochondrial $\mathrm{H} 2 \mathrm{O} 2$ production promotes endothelial NF-kappaB activation in aged rat arteries. Am J Physiol Heart Circ Physiol 2007;293(1):H37-47.

[49] Yang YM, Huang A, Kaley G, Sun D. eNOS uncoupling and endothelial dysfunction in aged vessels. Am J Physiol Heart Circ Physiol 2009;297(5):H1829-36.

[50] Droge W. Free radicals in the physiological control of cell function. Physiol Rev 2002;82(1):47-95.

[51] Vasquez-Vivar J, Kalyanaraman B, Martasek P, Hogg N, Masters BS, Karoui H, et al. Superoxide generation by endothelial 
nitric oxide synthase: The influence of cofactors. Proc Natl Acad Sci U S A 1998;95(16):9220-5.

[52] Vasquez-Vivar J, Kalyanaraman B. Generation of superoxide from nitric oxide synthase. FEBS Lett 2000;481(3):305-6.

[53] Edirisinghe I, Rahman I. Cigarette smoke-mediated oxidative stress, shear stress, and endothelial dysfunction: Role of VEGFR2.Ann N Y Acad Sci. 1203. United States2010 p. 66-72.

[54] Francia P, delli Gatti C, Bachschmid M, Martin-Padura I, Savoia C, Migliaccio E, et al. Deletion of p66shc gene protects against age-related endothelial dysfunction. Circulation 2004;110(18):2889-95.

[55] Rodríguez-Mañas L, El-Assar M, Vallejo S, López-Dóriga P, Solís J, Petidier R, et al. Endothelial dysfunction in aged humans is related with oxidative stress and vascular inflammation. Aging Cell 2009;8(3):226-38

[56] Labinskyy N, Csiszar A, Orosz Z, Smith K, Rivera A, Buffenstein $\mathrm{R}$, et al. Comparison of endothelial function, O2-* and $\mathrm{H} 2 \mathrm{O} 2$ production, and vascular oxidative stress resistance between the longest-living rodent, the naked mole rat, and mice. Am J Physiol Heart Circ Physiol 291. United States2006. p. H2698-704.

[57] Griendling KK, Sorescu D, Ushio-Fukai M. NAD(P)H oxidase: Role in cardiovascular biology and disease. Circ Res 2000;86(5):494-501.

[58] Wind S, Beuerlein K, Armitage ME, Taye A, Kumar AH, Janowitz D, et al. Oxidative stress and endothelial dysfunction in aortas of aged spontaneously hypertensive rats by NOX1/2 is reversed by NADPH oxidase inhibition. Hypertension. 56. United States2010. p. 490-7.

[59] Ungvari Z, Labinskyy N, Gupte S, Chander PN, Edwards JG, Csiszar A. Dysregulation of mitochondrial biogenesis in vascular endothelial and smooth muscle cells of aged rats. Am J Physiol Heart Circ Physiol 2008;294(5):H2121-8.

[60] Landmesser U, Spiekermann S, Dikalov S, Tatge H, Wilke $\mathrm{R}$, Kohler C, et al. Vascular oxidative stress and endothelial dysfunction in patients with chronic heart failure: Role of xanthine-oxidase and extracellular superoxide dismutase. Circulation 2002;106(24):3073-8

[61] Houston M, Estevez A, Chumley P, Aslan M, Marklund $S$, Parks DA, et al. Binding of xanthine oxidase to vascular endothelium. Kinetic characterization and oxidative impairment of nitric oxide-dependent signaling. J Biol Chem 1999;274(8):4985-94.

[62] White CR, Darley-Usmar V, Berrington WR, McAdams M, Gore JZ, Thompson JA, et al. Circulating plasma xanthine oxidase contributes to vascular dysfunction in hypercholesterolemic rabbits. Proc Natl Acad Sci U S A 1996;93(16):8745-9

[63] Newaz MA, Yousefipour Z, Oyekan A. Oxidative stressassociated vascular aging is xanthine oxidase-dependent but not $\mathrm{NAD}(\mathrm{P}) \mathrm{H}$ oxidase-dependent. J Cardiovasc Pharmacol 2006;48(3):88-94.

[64] Aranda R, Doménech E, Rus AD, Real JT, Sastre J, Viña J, et al. Age-related increase in xanthine oxidase activity in human plasma and rat tissues. Free Radic Res 2007;41(11):1195200.

[65] Farquharson CA, Butler R, Hill A, Belch JJ, Struthers AD. Allopurinol improves endothelial dysfunction in chronic heart failure. Circulation 2002;106(2):221-6.
[66] Doehner W, Schoene N, Rauchhaus M, Leyva-Leon F, Pavitt DV, Reaveley DA, et al. Effects of xanthine oxidase inhibition with allopurinol on endothelial function and peripheral blood flow in hyperuricemic patients with chronic heart failure: Results from 2 placebo-controlled studies. Circulation 2002;105(22):2619-24.

[67] O'Driscoll JG, Green DJ, Rankin JM, Taylor RR. Nitric oxide-dependent endothelial function is unaffected by allopurinol in hypercholesterolaemic subjects. Clin Exp Pharmacol Physiol 1999;26(10):779-83.

[68] Eskurza I, Kahn ZD, Seals DR. Xanthine oxidase does not contribute to impaired peripheral conduit artery endotheliumdependent dilatation with ageing. J Physiol 2006;571(Pt 3):661-8.

[69] Schmidt K, Werner ER, Mayer B, Wachter H, Kukovetz WR. Tetrahydrobiopterin-dependent formation of endotheliumderived relaxing factor (nitric oxide) in aortic endothelial cells. Biochem J 1992;281 ( Pt 2):297-300.

[70] Pierce GL, Larocca TJ. Reduced vascular tetrahydrobiopterin (BH4) and endothelial function with ageing: Is it time for a chronic BH4 supplementation trial in middle-aged and older adults? J Physiol. 586. England2008. p. 2673-4.

[71] Delp MD, Behnke BJ, Spier SA, Wu G, Muller-Delp JM. Ageing diminishes endothelium-dependent vasodilatation and tetrahydrobiopterin content in rat skeletal muscle arterioles. J Physiol 2008;586(4):1161-8.

[72] Sindler AL, Delp MD, Reyes R, Wu G, Muller-Delp JM. Effects of ageing and exercise training on eNOS uncoupling in skeletal muscle resistance arterioles. J Physiol 2009;587(Pt 15):3885-97.

[73] Blackwell KA, Sorenson JP, Richardson DM, Smith LA, Suda $\mathrm{O}$, Nath $\mathrm{K}$, et al. Mechanisms of aging-induced impairment of endothelium-dependent relaxation: Role of tetrahydrobiopterin. Am J Physiol Heart Circ Physiol 2004;287(6):H2448-53.

[74] Pierce GL, Jablonski KL, Walker AE, Seibert SM, Devan AE, Black SM, et al. Tetrahydrobiopterin supplementation enhances carotid artery compliance in healthy older men: A pilot study. Am J Hypertens. 25. United States2012. p. 10504.

[75] Lang JA, Holowatz LA, Kenney WL. Localized tyrosine or tetrahydrobiopterin supplementation corrects the age-related decline in cutaneous vasoconstriction. J Physiol 588. England2010. p. 1361-8.

[76] Csiszar A, Ungvari Z, Edwards JG, Kaminski P, Wolin MS, Koller A, et al. Aging-induced phenotypic changes and oxidative stress impair coronary arteriolar function. Circ Res 2002;90(11):1159-66.

[77] Csiszar A, Ungvari Z, Koller A, Edwards JG, Kaley G. Aginginduced proinflammatory shift in cytokine expression profile in coronary arteries. FASEB J 2003;17(9):1183-5.

[78] Singh T, Newman AB. Inflammatory markers in population studies of aging. Ageing Res Rev. 10. England: 2011. Published by Elsevier B.V.; 2011. p. 319-29.

[79] Monaco C, Paleolog E. Nuclear factor kappaB: A potential therapeutic target in atherosclerosis and thrombosis. Cardiovasc Res. 61. Netherlands2004. p. 671-82.

[80] Csiszar A, Labinskyy N, Smith K, Rivera A, Orosz Z, Ungvari $Z$. Vasculoprotective effects of anti-tumor necrosis factoralpha treatment in aging. Am J Pathol 2007;170(1):388-98. 
[81] Donato AJ, Pierce GL, Lesniewski LA, Seals DR. Role of NFkappaB in age-related vascular endothelial dysfunction in humans. Aging (Albany NY) 2009;1(8):678-80.

[82] Bruunsgaard H, Pedersen M, Pedersen BK. Aging and proinflammatory cytokines. Curr Opin Hematol 2001;8(3):131-6.

[83] Krabbe KS, Pedersen M, Bruunsgaard H. Inflammatory mediators in the elderly. Exp Gerontol. 39. England2004. pp. 687-99.

[84] Ashcroft GS, Horan MA, Ferguson MW. Aging alters the inflammatory and endothelial cell adhesion molecule profiles during human cutaneous wound healing. Lab Invest 1998;78(1):47-58

[85] Zou Y, Yoon S, Jung KJ, Kim CH, Son TG, Kim MS, et al. Upregulation of aortic adhesion molecules during aging. J Gerontol A Biol Sci Med Sci. 61. United States2006. p. 232-44.

[86] Chung HY, Sung B, Jung KJ, Zou Y, Yu BP. The molecular inflammatory process in aging. Antioxid Redox Signal 2006;8(3-4):572-81.

[87] Vita JA, Keaney JF, Larson MG, Keyes MJ, Massaro JM, Lipinska I, et al. Brachial artery vasodilator function and systemic inflammation in the Framingham Offspring Study. Circulation 2004;110(23):3604-9.

[88] Pierce GL, Lesniewski LA, Lawson BR, Beske SD, Seals DR. Nuclear factor-kappaB activation contributes to vascular endothelial dysfunction via oxidative stress in overweight/obese middle-aged and older humans. Circulation 2009;119(9):1284-92.

[89] Arenas IA, Xu Y, Davidge ST. Age-associated impairment in vasorelaxation to fluid shear stress in the female vasculature is improved by TNF-alpha antagonism. Am J Physiol Heart Circ Physiol 2006;290(3):H1259-63.

[90] Tian J, Yan Z, Wu Y, Zhang S-1, Wang K, Ma X-r, et al. Inhibition of iNOS protects endothelial-dependent vasodilation in aged rats. Acta Pharmacol Sin 2010;31(10): 1324-8.

[91] Esteve E, Castro A, Lopez-Bermejo A, Vendrell J, Ricart W, Fernandez-Real JM. Serum interleukin-6 correlates with endothelial dysfunction in healthy men independently of insulin sensitivity. Diabetes Care. 30. United States, 2007. p. 939-45.

[92] Wassmann S, Stumpf M, Strehlow K, Schmid A, Schieffer $\mathrm{B}$, Bohm M, et al. Interleukin-6 induces oxidative stress and endothelial dysfunction by overexpression of the angiotensin II type 1 receptor. Circ Res. 94. United States, 2004. p. 53441.

[93] Wei J, Xu H, Davies JL, Hemmings GP. Increase of plasma IL-6 concentration with age in healthy subjects. Life Sci. 1992;51(25):1953-6.

[94] Ferrucci L, Corsi A, Lauretani F, Bandinelli S, Bartali B, Taub $\mathrm{DD}$, et al. The origins of age-related proinflammatory state. Blood. 105. United States, 2005. p. 2294-9.

[95] Maggio M, Guralnik JM, Longo DL, Ferrucci L. Interleukin6 in aging and chronic disease: A magnificent pathway. J Gerontol A Biol Sci Med Sci. 61. United States, 2006. pp. 575-84.

[96] Sarkar D, Fisher PB. Molecular mechanisms of agingassociated inflammation. Cancer Lett. 236. Ireland, 2006. pp. 13-23.
[97] Hein TW, Singh U, Vasquez-Vivar J, Devaraj S, Kuo L, Jialal I. Human C-reactive protein induces endothelial dysfunction and uncoupling of eNOS in vivo. Atherosclerosis. 206. Ireland, 2009. p. 61-8.

[98] Singh U, Devaraj S, Vasquez-Vivar J, Jialal I. C-reactive protein decreases endothelial nitric oxide synthase activity via uncoupling. J Mol Cell Cardiol 2007;43(6):780-91.

[99] Clapp BR, Hirschfield GM, Storry C, Gallimore JR, Stidwill $\mathrm{RP}$, Singer $\mathrm{M}$, et al. Inflammation and endothelial function: Direct vascular effects of human C-reactive protein on nitric oxide bioavailability. Circulation 111. United States2005. p. 1530-6.

[100] Qamirani E, Ren Y, Kuo L, Hein TW. C-reactive protein inhibits endothelium-dependent NO-mediated dilation in coronary arterioles by activating p38 kinase and NAD(P)H oxidase. Arterioscler Thromb Vasc Biol. 25. United States, 2005. p. 995-1001.

[101] Zou Y, Jung KJ, Kim JW, Yu BP, Chung HY. Alteration of soluble adhesion molecules during aging and their modulation by calorie restriction. FASEB J. 18. United States, 2004. p. $320-2$.

[102] Steinberg D, Parthasarathy S, Carew TE, Khoo JC, Witztum JL. Beyond cholesterol. Modifications of low-density lipoprotein that increase its atherogenicity. N Engl J Med 1989;320(14):915-24.

[103] Galle J, Hansen-Hagge T, Wanner C, Seibold S. Impact of oxidized low density lipoprotein on vascular cells. Atherosclerosis 2006;185(2):219-26.

[104] Zuliani G, Morieri ML, Volpato S, Vigna GB, Tch CB, Maggio $\mathrm{M}$, et al. Determinants and clinical significance of plasma oxidized LDLs in older individuals. A 9 years follow-up study. Atherosclerosis 2013;226(1):201-7.

[105] Heitmann BL. The effects of gender and age on associations between blood lipid levels and obesity in Danish men and women aged 35-65 years. J Clin Epidemiol 1992;45(7):693702.

[106] Steer P, Sarabi DM, Karlström B, Basu S, Berne C, Vessby B, et al. The effect of a mixed meal on endothelium-dependent vasodilation is dependent on fat content in healthy humans. Clin Sci (Lond) 2003;105(1):81-7.

[107] Keogh JB, Grieger JA, Noakes M, Clifton PM. Flowmediated dilatation is impaired by a high-saturated fat diet but not by a high-carbohydrate diet. Arterioscler Thromb Vasc Biol 2005;25(6):1274-9.

[108] Esposito K, Marfella R, Ciotola M, Di Palo C, Giugliano F, Giugliano G, et al. Effect of a mediterranean-style diet on endothelial dysfunction and markers of vascular inflammation in the metabolic syndrome: A randomized trial. JAMA. 2004;292(12):1440-6.

[109] Tentolouris N, Arapostathi C, Perrea D, Kyriaki D, Revenas C, Katsilambros N. Differential effects of two isoenergetic meals rich in saturated or monounsaturated fat on endothelial function in subjects with type 2 diabetes. Diabetes Care 2008;31(12):2276-8.

[110] Grundy SM, Hansen B, Smith SC, Cleeman JI, Kahn RA, Association $\mathrm{AH}$, et al. Clinical management of metabolic syndrome: Report of the American Heart Association/National Heart, Lung, and Blood Institute/American Diabetes Association conference on scientific issues 
related to management. Arterioscler Thromb Vasc Biol 2004;24(2):e19-24. Association AH, et al. Clinical management of metabolic syndrome: Report of the American Heart Association/National Heart, Lung, and Blood Institute/American Diabetes Association conference on scientific issues related to management. Circulation 2004;109(4):551-6.

[112] Kingwell BA, Tran B, Cameron JD, Jennings GL, Dart AM. Enhanced vasodilation to acetylcholine in athletes is associated with lower plasma cholesterol. Am J Physiol 1996;270(6 Pt 2):H2008-13.

[113] Tetè S, Tripodi D, Rosati M, Conti F, Maccauro G, Saggini A, et al. Endothelial cells, cholesterol, cytokines, and aging. Int J Immunopathol Pharmacol 2012;25(2): $355-63$.

[114] Tesfamariam B, Cohen RA. Free radicals mediate endothelial cell dysfunction caused by elevated glucose. Am J Physiol 1992;263(2 Pt 2):H321-6.

[115] Gendron M-É, Thorin-Trescases N, Villeneuve L, Thorin E. Aging associated with mild dyslipidemia reveals that COX-2 preserves dilation despite endothelial dysfunction. American Journal of Physiology - Heart and Circulatory Physiology 2007;292(1):H451-H8

[116] Gobal FA, Mehta JL. Management of dyslipidemia in the elderly population. Therapeutic Advances in Cardiovascular Disease 2010;4(6):375-83.

[117] Trapani L, Pallottini V. Age-Related Hypercholesterolemia and HMG-CoA Reductase Dysregulation: Sex Does Matter (A Gender Perspective). Curr Gerontol Geriatr Res 2010:420139.

[118] Matasconi M, Parini P, Angelin B, Rudling M. Pituitary control of cholesterol metabolism in normal and LDL receptor knock-out mice: Effects of hypophysectomy and growth hormone treatment. Biochim Biophys Acta 2005;1736(3):221-7.

[119] Khaw KT, Barrett-Connor E. Endogenous sex hormones, high density lipoprotein cholesterol, and other lipoprotein fractions in men. Arterioscler Thromb 1991;11(3):489-94.

[120] Andersen AG, Jensen TK, Carlsen E, Jørgensen N, Andersson AM, Krarup T, et al. High frequency of sub-optimal semen quality in an unselected population of young men Hum Reprod. 2000;15(2):366-72.

[121] Nappo F, Esposito K, Cioffi M, Giugliano G, Molinari AM, Paolisso G, et al. Postprandial endothelial activation in healthy subjects and in type 2 diabetic patients: Role of fat and carbohydrate meals. J Am Coll Cardiol 2002;39(7):1145-50.

[122] van Meijl LE, Mensink RP. Effects of low-fat dairy consumption on markers of low-grade systemic inflammation and endothelial function in overweight and obese subjects: An intervention study. Br J Nutr 2010;104(10):1523-7.

[123] Ong PJ, Dean TS, Hayward CS, Della Monica PL, Sanders TA, Collins P. Effect of fat and carbohydrate consumption on endothelial function. Lancet 1999;354(9196):2134.

[124] Mittermayer F, Schaller G, Pleiner J, Krzyzanowska K, Kapiotis S, Roden M, et al. Rosiglitazone prevents free fatty acid-induced vascular endothelial dysfunction. J Clin Endocrinol Metab 2007;92(7):2574-80.

[125] Settergren M, Böhm F, Rydén L, Pernow J. Cholesterol lowering is more important than pleiotropic effects of statins for endothelial function in patients with dysglycaemia and coronary artery disease. Eur Heart J 2008;29(14): 1753-60.

[126] Sheu WH, Chen YT, Lee WJ. Improvement in endothelial dysfunction with LDL cholesterol level $<80 \mathrm{mg} / \mathrm{dl}$ in type 2 diabetic patients. Diabetes Care 2001;24(8): 1499-501.

[127] Libby P, Ridker PM, Hansson GK. Progress and challenges in translating the biology of atherosclerosis. Nature 2011;473(7347):317-25.

[128] Ross R. Atherosclerosis-an inflammatory disease. N Engl J Med 1999;340(2):115-26.

[129] Davignon J, Ganz P. Role of endothelial dysfunction in atherosclerosis. Circulation 2004;109(23 Suppl 1):III27-32.

[130] Liu S, Willett WC, Stampfer MJ, Hu FB, Franz M, Sampson $\mathrm{L}$, et al. A prospective study of dietary glycemic load, carbohydrate intake, and risk of coronary heart disease in US women. Am J Clin Nutr 2000;71(6):1455-61.

[131] Jeppesen J, Schaaf P, Jones C, Zhou MY, Chen YD, Reaven GM. Effects of low-fat, high-carbohydrate diets on risk factors for ischemic heart disease in postmenopausal women. Am J Clin Nutr 1997;65(4):1027-33.

[132] Willett W, Manson J, Liu S. Glycemic index, glycemic load, and risk of type 2 diabetes. Am J Clin Nutr 2002;76(1):274S$80 \mathrm{~S}$.

[133] Buscemi S, Cosentino L, Rosafio G, Morgana M, Mattina A, Sprini D, et al. Effects of hypocaloric diets with different glycemic indexes on endothelial function and glycemic variability in overweight and in obese adult patients at increased cardiovascular risk. Clin Nutr 2013;32(3):346-52.

[134] Wolff SP, Jiang ZY, Hunt JV. Protein glycation and oxidative stress in diabetes mellitus and ageing. Free Radic Biol Med 1991;10(5):339-52.

[135] Gradinaru D, Borsa C, Ionescu C, Margina D. Advanced oxidative and glycoxidative protein damage markers in the elderly with type 2 diabetes. J Proteomics 2013;92:313-22.

[136] Quijano C, Castro L, Peluffo G, Valez V, Radi R. Enhanced mitochondrial superoxide in hyperglycemic endothelial cells: Direct measurements and formation of hydrogen peroxide and peroxynitrite. Am J Physiol Heart Circ Physiol 2007;293(6):H3404-14.

[137] Cai S, Khoo J, Mussa S, Alp NJ, Channon KM. Endothelial nitric oxide synthase dysfunction in diabetic mice: Importance of tetrahydrobiopterin in eNOS dimerisation. Diabetologia 2005;48(9):1933-40.

[138] Frey RS, Ushio-Fukai M, Malik AB. NADPH oxidasedependent signaling in endothelial cells: Role in physiology and pathophysiology. Antioxid Redox Signal 2009;11(4):791-810.

[139] Giacco F, Brownlee M. Oxidative stress and diabetic complications. Circ Res 2010;107(9):1058-70.

[140] Kränkel N, Adams V, Linke A, Gielen S, Erbs S, Lenk K, et al. Hyperglycemia reduces survival and impairs function of circulating blood-derived progenitor cells. Arterioscler Thromb Vasc Biol 2005;25(4):698-703.

[141] Goldin A, Beckman JA, Schmidt AM, Creager MA. Advanced glycation end products: Sparking the development of diabetic vascular injury. Circulation 2006;114(6): 597-605. 
[142] Neeper M, Schmidt AM, Brett J, Yan SD, Wang F, Pan YC, et al. Cloning and expression of a cell surface receptor for advanced glycosylation end products of proteins. J Biol Chem 1992;267(21):14998-5004.

[143] Wautier MP, Boulanger E, Guillausseau PJ, Massin P, Wautier JL. AGEs, macrophage colony stimulating factor and vascular adhesion molecule blood levels are increased in patients with diabetic microangiopathy. Thromb Haemost 2004;91(5):879-85.

[144] Xu B, Ji Y, Yao K, Cao YX, Ferro A. Inhibition of human endothelial cell nitric oxide synthesis by advanced glycation end-products but not glucose: Relevance to diabetes. Clin Sci (Lond) 2005;109(5):439-46.

[145] Gao L, Liu WH, Luan NN, Feng C, Shang T. [Correlation between the expression of high mobility group box 1 and receptor for advanced glycation end products and the onset of pre-eclampsia]. Zhonghua Fu Chan Ke Za Zhi 2008;43(10):746-50.

[146] Forbes JM, Yee LT, Thallas V, Lassila M, Candido R, Jandeleit-Dahm KA, et al. Advanced glycation end product interventions reduce diabetes-accelerated atherosclerosis. Diabetes 2004;53(7):1813-23.

[147] Kass DA, Shapiro EP, Kawaguchi M, Capriotti AR, Scuteri A, deGroof RC, et al. Improved arterial compliance by a novel advanced glycation end-product crosslink breaker. Circulation 2001;104(13):1464-70.

[148] Brasacchio D, Okabe J, Tikellis C, Balcerczyk A, George P, Baker EK, et al. Hyperglycemia induces a dynamic cooperativity of histone methylase and demethylase enzymes associated with gene-activating epigenetic marks that coexist on the lysine tail. Diabetes 2009;58(5):1229-36.

[149] Mortuza R, Chen S, Feng B, Sen S, Chakrabarti S. High glucose induced alteration of SIRTs in endothelial cells causes rapid aging in a p300 and FOXO regulated pathway. PLoS One 2013;8(1):e54514.

[150] Bale GS, Entmacher PS. Estimated life expectancy of diabetics. Diabetes 1977;26(5):434-8.

[151] Avogaro A, de Kreutzenberg SV, Federici M, Fadini GP. The endothelium abridges insulin resistance to premature aging. J Am Heart Assoc 2013;2(3):e000262.

[152] Mattagajasingh I, Kim CS, Naqvi A, Yamamori T, Hoffman TA, Jung SB, et al. SIRT1 promotes endothelium-dependent vascular relaxation by activating endothelial nitric oxide synthase. Proc Natl Acad Sci U S A 2007;104(37):14855-60.

[153] Brown AA, Hu FB. Dietary modulation of endothelial function: Implications for cardiovascular disease. Am J Clin Nutr 2001;73(4):673-86.

[154] Silver HJ, Kang H, Keil CD, Muldowney JA, Kocalis H, Fazio S, et al. Consuming a balanced high fat diet for 16 weeks improves body composition, inflammation and vascular function parameters in obese premenopausal women. Metabolism 2014.

[155] Sijtsma FP, Meyer KA, Steffen LM, Van Horn L, Shikany JM, Odegaard AO, et al. Diet quality and markers of endothelial function: The CARDIA study. Nutr Metab Cardiovasc Dis 2014.

[156] Ballard KD, Quann EE, Kupchak BR, Volk BM, Kawiecki DM, Fernandez ML, et al. Dietary carbohydrate restriction improves insulin sensitivity, blood pressure, microvascular function, and cellular adhesion markers in individuals taking statins. Nutr Res 2013;33(11):905-12.

[157] Davis NJ, Crandall JP, Gajavelli S, Berman JW, Tomuta N, Wylie-Rosett J, et al. Differential effects of low-carbohydrate and low-fat diets on inflammation and endothelial function in diabetes. J Diabetes Complications 2011;25(6):371-6.

[158] Lopez-Garcia E, Schulze MB, Fung TT, Meigs JB, Rifai $\mathrm{N}$, Manson JE, et al. Major dietary patterns are related to plasma concentrations of markers of inflammation and endothelial dysfunction. Am J Clin Nutr 2004;80(4): 1029-35.

[159] Davis N, Katz S, Wylie-Rosett J. The effect of diet on endothelial function. Cardiol Rev 2007;15(2):62-6.

[160] Tresserra-Rimbau A, Rimm EB, Medina-Remón A, Martínez-González MA, de la Torre R, Corella D, et al. Inverse association between habitual polyphenol intake and incidence of cardiovascular events in the PREDIMED study. Nutr Metab Cardiovasc Dis 2014.

[161] Vita JA. Polyphenols and cardiovascular disease: Effects on endothelial and platelet function. Am J Clin Nutr 2005;81(1 Suppl):292S-7S.

[162] Duffy SJ, Keaney JF, Holbrook M, Gokce N, Swerdloff PL, Frei B, et al. Short- and long-term black tea consumption reverses endothelial dysfunction in patients with coronary artery disease. Circulation 2001;104(2):151-6.

[163] Stein JH, Keevil JG, Wiebe DA, Aeschlimann S, Folts JD. Purple grape juice improves endothelial function and reduces the susceptibility of LDL cholesterol to oxidation in patients with coronary artery disease. Circulation 1999;100(10):1050-5.

[164] Rodriguez-Mateos A, Rendeiro C, Bergillos-Meca T, Tabatabaee S, George TW, Heiss C, et al. Intake and time dependence of blueberry flavonoid-induced improvements in vascular function: A randomized, controlled, double-blind, crossover intervention study with mechanistic insights into biological activity. Am J Clin Nutr 2013;98(5):1179-91.

[165] Malireddy S, Kotha SR, Secor JD, Gurney TO, Abbott JL, Maulik G, et al. Phytochemical antioxidants modulate mammalian cellular epigenome: Implications in health and disease. Antioxid Redox Signal 2012;17(2):327-39.

[166] Galleano M, Pechanova O, Fraga CG. Hypertension, nitric oxide, oxidants, and dietary plant polyphenols. Curr Pharm Biotechnol 2010;11(8):837-48.

[167] Manach C, Williamson G, Morand C, Scalbert A, Rémésy C. Bioavailability and bioefficacy of polyphenols in humans. I. Review of 97 bioavailability studies. Am J Clin Nutr 2005;81(1 Suppl):230S-42S.

[168] Scalbert A, Johnson IT, Saltmarsh M. Polyphenols: Antioxidants and beyond. Am J Clin Nutr 2005;81(1 Suppl):215S-7S.

[169] Masella R, Di Benedetto R, Varí R, Filesi C, Giovannini C. Novel mechanisms of natural antioxidant compounds in biological systems: involvement of glutathione and glutathione-related enzymes. J Nutr Biochem 2005;16(10):577-86.

[170] Vauzour D, Rodriguez-Mateos A, Corona G, Oruna-Concha MJ, Spencer JP. Polyphenols and human health: Prevention of disease and mechanisms of action. Nutrients 2010;2(11):1106-31. 
[171] Ellis CL, Edirisinghe I, Kappagoda T, Burton-Freeman B. Attenuation of meal-induced inflammatory and thrombotic responses in overweight men and women after 6-week daily strawberry (Fragaria) intake. A randomized placebocontrolled trial. J Atheroscler Thromb 18. Japan2011. pp. 318-27.

[172] Burton-Freeman B. Postprandial metabolic events and fruitderived phenolics: A review of the science. $\mathrm{Br} \mathrm{J}$ Nutr. 2010;104 Suppl 3:S1-14.

[173] Kris-Etherton PM, Lefevre M, Beecher GR, Gross MD, Keen CL, Etherton TD. Bioactive compounds in nutrition and health-research methodologies for establishing biological function: The antioxidant and anti-inflammatory effects of flavonoids on atherosclerosis. Annu Rev Nutr 2004;24:51138.

[174] Title LM, Cummings PM, Giddens K, Genest JJ, Nassar BA. Effect of folic acid and antioxidant vitamins on endothelial dysfunction in patients with coronary artery disease. J Am Coll Cardiol 2000;36(3):758-65.

[175] Dietary Guidelines for Americans, 2010. Government Printing Office, Washington D.C: 2010.
[176] Oberleithner H. Two barriers for sodium in vascular endothelium? Ann Med. 2012;44 Suppl 1:S143-8.

[177] Aaron KJ, Sanders PW. Role of dietary salt and potassium intake in cardiovascular health and disease: A review of the evidence. Mayo Clin Proc 2013;88(9):987-95.

[178] Salehi-Abargouei A, Maghsoudi Z, Shirani F, Azadbakht L. Effects of Dietary Approaches to Stop Hypertension (DASH)-style diet on fatal or nonfatal cardiovascular diseases-incidence: A systematic review and metaanalysis on observational prospective studies. Nutrition 2013;29(4):611-8.

[179] Boegehold MA. The effect of high salt intake on endothelial function: Reduced vascular nitric oxide in the absence of hypertension. J Vasc Res 2013;50(6):458-67.

[180] Lien LF, Brown AJ, Ard JD, Loria C, Erlinger TP, Feldstein AC, et al. Effects of PREMIER lifestyle modifications on participants with and without the metabolic syndrome. Hypertension 2007;50(4):609-16.

[181] Vogel RA. Coronary risk factors, endothelial function, and atherosclerosis: A review. Clin Cardiol 1997;20(5):426-32. 